\title{
Crabs in Bandealit Estuary Resort of Meru Betiri National Park
}

\author{
Galuh Paramita ${ }^{1}$, Wachju Subchan², Vendi Eko Susilo ${ }^{3}$ \\ Pendidikan Biologi, Fakultas Keguruan dan Ilmu Pendidikan, Universitas Jember \\ Jl. Kalimantan 37, Jember 68121 \\ email: wachju.fkip@unej.ac.id
}

\begin{abstract}
Crabs are macrobenthos with characters that are attached to or resting on a base or live on sediments. The role of crabs in the ecosystem includes converting nutrients and enhancing mineralization, increasing the distribution of oxygen in the soil, helping carbon life cycles, and providing natural food for various types of aquatic biota. This research was conducted in the estuary area of the Meru Betiri National Park (TNMB) Resort Bandealit. Identification results from 37 individual crabs at the Estuary Resort Bandealit Meru Betiri National Park (TNMB) obtained five species from 2 families (Portunidae and Sesarmidae). In the family Portunidae, there are three types, namely Scylla tranquebarica, Scylla paramamosain, and Scylla olivacea. Whereas in the family of Sesarmidae found two types, namely Parasesarma pictum and Parasesarma cognatum.
\end{abstract}

\section{Keywords: Crab, Bandealit Resort, Identification}

\section{PRELIMINARY}

Indonesia is a country with abundant natural resources. Its natural potential starts from the sea and land (Zulkarnain et al., 2013). The total area of Indonesian waters covers $75 \%$ of the surface, divided into two main categories, namely freshwater ecosystems and seawater ecosystems. Of the two aquatic ecosystems, seawater has the largest share of more than $97 \%$, and the rest is freshwater, which is very important for humans to live their activities (Barus, 1996). The dominating sea area causes Indonesia's coastal and marine areas to have the most abundant marine biodiversity in the world (Silulu et al., 2013).

Coastal ecosystems have areas that are inundated continuously, and some are only for a moment. Based on the nature of the ecosystem, coastal ecosystems can be natural or artificial (human-made). Natural ecosystems in coastal areas include coral reefs, mangroves, seagrass beds, sandy beaches, rocky beaches, rocky beaches, escape formations, Barrington formations, lagoons, lagoons, delta, and estuary while artificial ecosystems include ponds, tidal paddy fields, tourism areas, industrial areas and residential areas (Narwan, 2011).

The estuary is one of the coastal ecosystems with semi-closed waters that is free of contact with the sea and is still under the influence of freshwater from rivers so that seawater with high salinity can be mixed with fresh water (Dyer, 1986). The existence of a continuous flow from rivers, as well as the movement of water due to tidal currents that lift minerals, organic matter, and sediments, are the essential ingredients supporting the productivity of waters in the estuary region that exceeds the productivity of the high seas and freshwater waters (Bengen, 2004).

An estuary environment is a nutrientrich environment, which is the most crucial element for phytoplankton growth. It becomes a unique character in the estuary ecosystem. An estuary is known as the nursery ground for fish and invertebrate (Crab, Bivalve, Echinoderms, Annelida) (Begen, 2002). Crabs are macrobenthos that attached to or resting on sediments (Hariyanto et al., 2008). Polluted waters will affect the survival of macrobenthos. Crabs serve as a bioindicator of water quality because of its relatively permanent habitat. Changes in the quality of water and substrates will affect the abundance and diversity of crabs and other biotas (Sembiring, 2008; Purnami et al., 2010; Worm et al., 2012).

Crabs have a role as a key species (keystone species) in nature. Key species have an impact on the diversity of other biotas. Therefore their extinction will cause the extinction of other biotas (Menge et al., 2001). The role of crabs in the ecosystem includes converting nutrients and enhancing mineralization, increasing the distribution of 
oxygen in the soil, helping carbon life cycles, and providing natural food for various types of aquatic biota (Prianto, 2007).

Soedibjo and Aswandy, in their 2007 study in Teluk Besar, obtained the crab species that lived in the Gilimanuk estuary area, succeeded in getting 13 types of crabs from 5 tribes/families. It partly means that the mangrove and estuarine areas of West Bali National Park have a high level of diversity of crab species (Soedibjo and Aswandy, 2007).

In contrast to the research of Putriningtias et al. (2014), in mangrove track of the Karimunjawa National Park. She found only four families (Grapsidae, Ocypodidae, Macrophthalmidae, and Portunidae). The diversity is in low criteria $\mathrm{H}^{\prime}=<1$, which means crabs are disturbed by the environmental quality and difficult to adapt to existing environmental conditions.

The vegetation of Meru Betiri National Park shows 518 species of flora, consisting of 15 protected species and 503 abundant species. On the other hand, 217 species of fauna have been identified, consisting of 92 protected species and 115 unprotected species. As much as 25 species of mammals (18 of which are protected) live in the region, eight reptiles (6 of which are protected), and 184 species of birds (68 of which are protected) (Meru Betiri National Park Office, 2002). However, there is no data on the diversity of crabs. Researchers need to identify crabs in the Estuary Resort Bandealit TNMB area to determine the potential wealth of crabs that lead to conservation policies and provide additional information about various types of crabs found in the Estuary Resort Bandealit TNMB area. The results of crabs identification in the region can be compiled as popular scientific books to provide insight into the public.

\section{RESEARCH METHODS}

\section{Place and time of research}

The location of the study was conducted at the Estuary of Bandealit Beach, Meru Betiri National Park, from December 2018 until February 2019.

\section{Tools and Materials}

The tools used in this study were traps, storage boxes, Hanna $\mathrm{pH}$ meters, Atago refractometers, digital cameras, stationery, rulers, and reference books for crab identification, namely living marine resources of the western central pacific (Kent E. Carpenter, 1998). The materials used in this study were crab samples, millimeter paper, plastic bags, raffia ropes, label paper, and local fish (Sardinella lemuru) as crab bait.

\section{Data Collection Techniques}

Crabs were caught using Bubu traps. Sampling is done by purposive sampling and road sampling methods. The abiotic factors were also measured in the form of water $\mathrm{pH}$, water salinity, and the type of substrate.

The technique for taking crabs using Bubu is as follows:

1) Open the trap lid, put the bait, and close the lid. A small door in the inner compartment will shut when crab enters, blocking the crab from coming out. 2) Once it got caught, the crab immediately cleaned with water and stored in a plastic tub labeled for later preserved with $70 \%$ alcohol. 


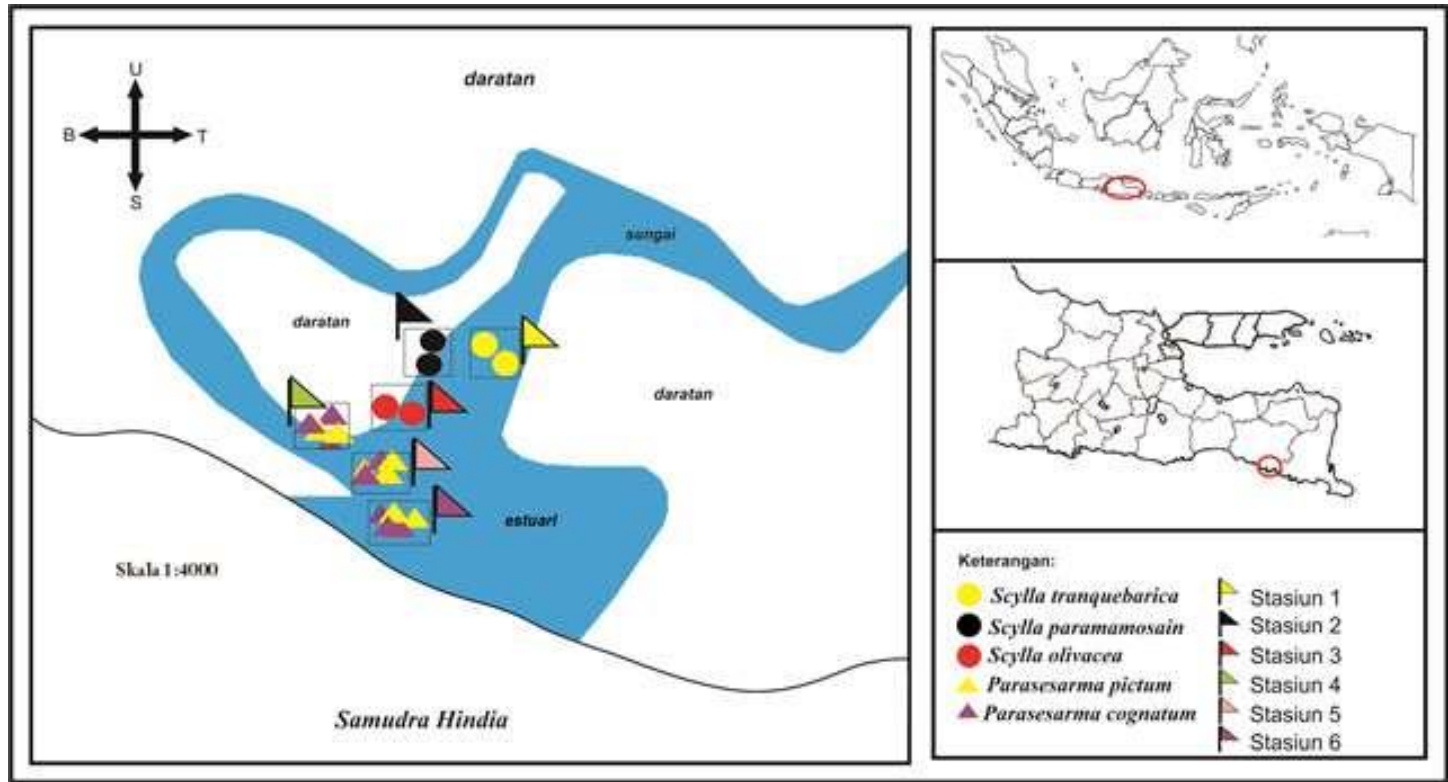

Figure 1.1 Map of the Distribution of Crab Habitat in the Estuary of the Meru Betiri National Park

\section{RESULTS AND DISCUSSION}

Table 1 presents the results of crab identification obtained from the Bandealit Resort Meru Betiri National Park, conducted in March 2019.

Table 1. Results of identification of crabs in the Bandealit Resort Meru Betiri National Park

\begin{tabular}{llll}
\hline No. & Family & Genus & Species \\
\hline 1 & Portunidae & Scylla & Scylla tranquebarica \\
\hline 2 & Portunidae & Scylla & Scylla paramamosain \\
\hline 3 & Portunidae & Scylla & Scylla olivacea \\
\hline 4 & Sesarmidae & Parasesarma & Parasesarma pictum \\
\hline 5 & Sesarmidae & Parasesarma & Parasesarma cognatum \\
\hline
\end{tabular}

The identification of crab samples referred to Carpenter (1998) and Community Foundation Indonesian Fisheries (2017). Based on Table 1, the specimens, classification, and description of the samples are as follows.

1) Scylla tranquebarica

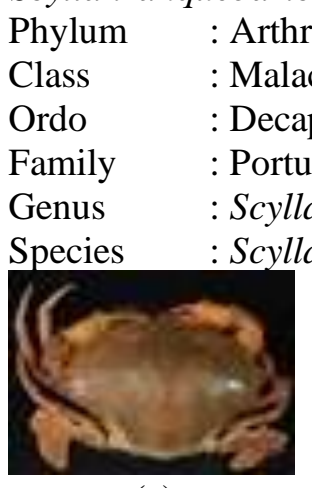

(a)
Arthropoda

Malacostraca

Scylla

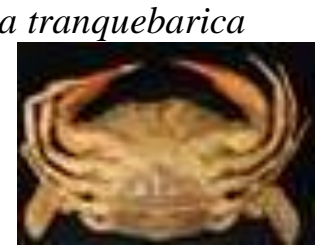

(b)
Description:

Scylla tranquebarica is only found at the first sampling station with a muddy substrate. The sample here is female. Scylla tranquebarica is brownish red, oval-shaped 12 $\mathrm{cm}$ width carapace. These crabs can have a carapace width up to $20 \mathrm{~cm}$ and have nine sharp spines along the edge of the carapace and also on the leg joints. Carapace ridges are usually dark orange to brown, and chela can be orange or red with a visible $\mathrm{H}$-shaped groove. Scylla tranquebarica has a hefty chela. The carpus has two sharp spines, and the propondus spine is shiny, while the frontal lobe is dull and has a medium height.

Figure 1.2 (a) Scylla tranquebarica appears dorsal; (b) Scylla tranquebarica appears to be ventral (Source: Personal Document). 
2) Scylla paramamosain

Phylum: Arthropoda

Class: Malacostraca

Ordo: Decapoda

Family: Portunidae

Genus: Scylla

Species: Scylla paramamosain

(Estampador, 1950)

Distribution: Southeast Asia, especially on the north coast of the South China Sea and parts of Java.

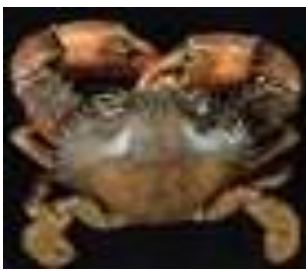

(a)

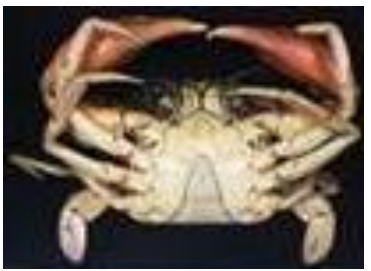

(b)
Description:

Scylla paramamosain is only found at the $2^{\text {nd }}$ sampling station with a muddy substrate. These samples are male. This crab has a carapace width of $12 \mathrm{~cm}$, elongated round shape, and somewhat convex with a visible $\mathrm{H}$-shaped groove. There are nine spines of varying shape and sharpness on the left and right anterolateral edges of the carapace, or in the branchial region. While on the front of the carapace, or in the gastric region, right between the two eyestalks, there are six sturdy spines on the top, and two sturdy spines on the bottom left and right. The first pair of spines on the left and right anterolateral carapace, as well as two pairs on the top and bottom of the carapace, are in a position around the eye socket. These spines serve to protect the eye. Carapace posterior vary from purple-green to brown-black. Scylla paramamosain has a hefty chela. Carpus spines are apparent but not as sharp as Scylla tranquebarica, and medium frontal lobe spines are triangular with straight edges.

\section{3) Scylla olivacea}

Phylum: Arthropoda

Class: Malacostraca

Ordo: Decapoda

Family: Portunidae

Genus: Scylla

Species: Scylla olivacea (Herbst, 1796)

Distribution: Southeast Asia, especially in the Sunda Islands
Habitat: Specimens collected from estuarine ecosystems dominated by Rhizophora sp. with mud substrate.

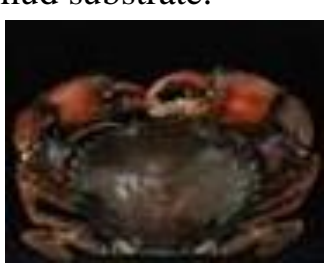

(a)

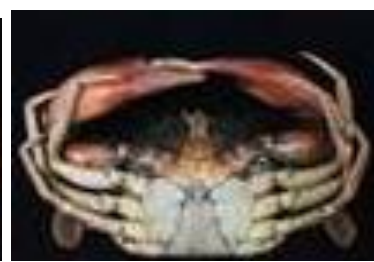

(b)
Description:

Scylla olivacea found only on the $3^{\text {rd }}$ sampling station with a muddy substrate. These samples are male. Scylla olivacea has a $12 \mathrm{~cm}$ width carapace. Scylla olivacea can reach a carapace width of $18 \mathrm{~cm}$. Chela is large, sturdy, range from reddish black and orange to red or brick red, and does not have a pattern of spotting on the swimming legs and arm claws. Scylla olivacea has an elongated round carapace, and there is a visible $\mathrm{H}$-shaped groove. Scylla olivacea has nine sharp spines along the edge of the carapace's back and also in the leg joints. There are reddish-brown lines on almost all parts of the body, including the chela except the stomach. The spines on the propondus are small and reduced while the carpus spines are apparent but not as sharp as Scylla paramamosain, the thorns of the frontal lobes are medium and triangular with a straight edge.

\section{4) Parasesarma pictum}

Phylum: Arthropoda

Class: Malacostraca

Ordo: Decapoda

Family: Sesarmidae

Genus: Parasesarma

Species: Parasesarma pictum

Distribution: East Asia

Habitat: Specimens collected from estuarine ecosystems dominated by Rhizophora sp. with sandy substrate.

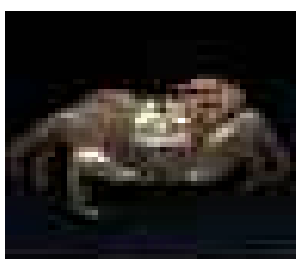

(a)

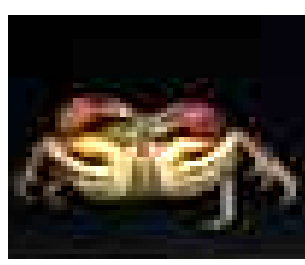

(b)
Description:

Parasesarma pictum was found at the $4^{\text {th }}, 5^{\text {th }}$, and $6^{\text {th }}$ sampling stations four. This 
sample was male with $2 \mathrm{~cm}$ in length of the carapace. Parasesarma pictum has a squareshaped carapace. The carapace surface has an apparent, smooth division area, and there are short scattered setae. There is a shallow frontal margin in the middle, a notched front with a slightly concave center. The chalice is covered with scaly tubercles that disappear with ages and several short (hair) setae. The inside of the crab chela has a fine texture, even though there are bumps and patterns on the legs. The upper part (merus) of the foot of the Parasesarma pictum road is relatively broad from the lower limbs.

\section{5) Parasesarma cognatum}

Phylum: Arthropoda

Class: Malacostraca

Ordo: Decapoda

Family: Sesarmidae

Genus: Parasesarma

Species: Parasesarma cognatum

(Rahayu \& J-J Li, 2013)

Distribution: East Asia, Taiwan, and the

Philippines

Habitat: Specimens collected from estuarine ecosystems dominated by Rhizophora sp. with sandy substrate.

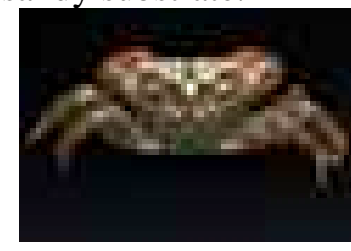

(a)

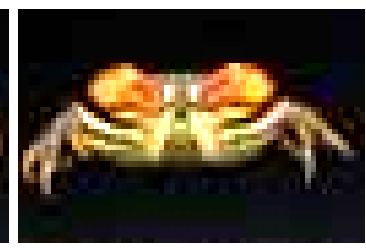

(b)
Description:

Parasesarma cognatum was found at the $4^{\text {th }}, 5^{\text {th }}$, and $6^{\text {th }}$ sampling stations. The sample was male with a carapace length of $2 \mathrm{~cm}$. The carapace is square and separated by an apparent groove, a notched-out two-sided front with a slightly concave center. There is a short seta along the edge of the carapace. The carapace surface has an apparent, smooth division of the area, the gastric region is visible, and the branchial region has a prominent line. Parasesarma cognatum lateral surface is coated with strong sloping striae, whereas on the dorsal surface, it has many short setae beams, lateral margins with short setae. The postfrontal region is separated into four lobes by narrow and deep grooves and at a median lobe that is the same width as the lateral lobe.

\section{CONCLUSION}

Crabs found at the Estuary Resort Bandealit Meru Betiri National Park (TNMB), there are five types of 2 families (Portunidae and Sesarmidae). In the family Portunidae, there are Scylla tranquebarica, Scylla paramamosain, and Scylla olivacea. Whereas in the family of Sesarmidae, there are Parasesarma pictum and Parasesarma cognatum.

\section{BIBLIOGRAPHY}

Begen, D. G., 2002. Ekosistem dan Sumberdaya Alam Pesisir dan Laut Serta Prinsip Pengelolaannya. Bogor: PK-SPL. IPB.

Bengen, D.G., 2004. Menuju Pengelolaan Wilayah Pesisir Terpadu Berbasis Daerah Aliran Sungai (DAS), Dalam Interaksi Daratan dan Lautan: Pengaruhnya terhadap Sumber Daya dan Lingkungan, Prosiding Simposium Interaksi Daratan dan Lautan. Diedit Oleh W.B. Setyawan, dkk. Jakarta: Kedeputian Ilmu Pengetahuan Kebumian, Lembaga Ilmu Pengetahuan Indonesia.

Balai Taman Nasional Meru Betiri (BTNMB). 2002. Social Forestry di TNMB: Model Kemitraan Rehabilitasi Kawasan. Jember: Balai Taman Nasional Meru Betiri Jember.

Carpenter, Kent. E. \& Niem, Volker. H. 1998. The Living Marine Resource of the Western Central Pacific. Cephalopods, Crustaceans, Holothurians, and Shark. Rome, Italy: Food and Agriculture Organization of the United Nations Vol 2.

Dyer K. R.1986. Coastal and Estuarine Sediment Dynamics. London: John Wiley \& Sons.

Menge BA, Freudenburg TL. 2001. Keystone Species. J Encof Bio 3:613- 629.

Prianto, E., 2007. Peran Kepiting sebagai Spesies Kunci (Keystone Spesies) pada Ekosistem Mangrove. Prosiding Forum Perairan Umum Indonesia IV. Banyuasin: Balai Riset Perikanan Perairan Umum. 
Purnami AT, Sunarto, Setyono P. 2010. Study of Bentos Community Based on Diversity and Similarity Index in Cengklik DAM Boyolali. Ekosains 2 (2): 50-65.

Putriningtias, andika, Dietriech geoffreybengen, Mohammad kasim moosa. 2014. Structure and Relationship of Crabs (Brachyura) With The Environment at Mangrove Ecosystem Canal Areas, Karimunjawa National Park, Central Java. Bonorowo Wetlands 4(2): 8293.

Sembiring, H. 2008. Keanekaragaman dan Distribusi Udang Serta Kaitannya dengan Faktor Fisik Kimia di Perairan Pantai Labu Kabupaten Deli Serdang. Medan: Sekolah Pascasarjana, Universitas Sumatera Utara.

Silulu, Pieter F, Farnis B Boneka, Gustaf F. Mamangkey. 2013. Biodiversitas Kerang Oyster (Mollusca, Bivalvia) di Daerah Intertidal Halmahera Barat, Maluku Utara. Jurnal Ilmiah Platax Vol. I-2.

Soedibjo BS dan I Aswandy. 2007. Pengaruh Tipe Ekosistem Terhadap Struktur Komunitas Kerustasea di Teluk Gilimanuk, Bali Barat. Oseanologi \& Limnologi 33, 455-467.

Zulkarnain, M., Pudji Purwanti, Erlinda Indrayani. 2013. Analisis Pengaruh Nilai Produksi Perikanan Budidaya terhadap Produk Domestik Bruto Sektor Perikanan di Indonesia. Jurnal ECSOFiM Vol. 1 No. 1. 